\title{
Influence of Organic Loading Rate on the Anaerobic Digestion of Mixed Faecal Sludge and Organic Waste
}

\author{
Hoang Le Phuong
}

\begin{abstract}
The aim of this study was to investigate the effect of substrate loading rate on anaerobic digestion using composite biogas tank with the climate of Vietnam. The study was done in three trails with fresh material was faecal sludge (FS) and organic waste $(\mathrm{OW})$ mixed at ratio $\mathrm{FS}: \mathrm{OW}=3: 1$ about weight. The fesh material was loaded batch and kept for digestion in 30 days after that the reactor was operated at three different loading rates $\mathrm{VS}=1.0 \pm 0.1 \mathrm{kgVS} / \mathrm{m}^{3}$.day in trail $1,1.5 \pm 0.1$ $\mathrm{kgVS} / \mathrm{m}^{3}$.day in trail 2 and $2.0 \pm 0.1 \mathrm{kgVS} / \mathrm{m}^{3}$.day in trail 3. The obtained results during anaerobic digestion indicated that when increased loading rate from $1.0 \pm 0.1 \mathrm{kgVS} / \mathrm{m}^{3}$.day to $1.5 \pm 0.1$ $\mathrm{kgVS} / \mathrm{m}^{3}$.day the yeild biogas also rised from $284 \mathrm{NI} / \mathrm{kgVS}$ of the feed to $490.32 \mathrm{NI} / \mathrm{kgVS}$ of the feed with $\mathrm{CH}_{4}$ content higher than $60 \%$. However, at loading rate $2 \pm 0.1 \mathrm{kgVS} / \mathrm{m}^{3}$.day the yield of biogas product reduced to $236.11 \mathrm{NI} / \mathrm{kgVS}$ of the feed with $\mathrm{CH}_{4}$ content lower than $50 \%$. It can see that the organic loading rate $1.5 \pm 0.1 \mathrm{kgVS} / \mathrm{m}^{3}$.day is suitable for anaerobic co-digestion of faecal sludge and organic waste.
\end{abstract}

Index Terms - Anaerobic digestion, biogas, faecal sludge, organic loading rate.

\section{INTRODUCTION}

In urban areas of Vietnam, the majority of houses uses septic tank as one-site sanitation because of simplicity and stably. Besides, it also has public toilets in some cities. There are about $77 \%$ of households in urban, $40 \%$ in suburban and $19 \%$ in rural use septic tank [1]. The efficiency of BOD and suspended solids treatment of the septic tank usually ranges from 0 to $50 \%$ depending on the design of septic tank, water discharge and habit of emptying tanks so the organic matter in feacal sludge is usually high [1]. Meanwhile, the amount of feacal sludge generated each year is quite large, specific in Hanoi and Ho Chi Minh cities about 500 tons per day [2]. Moreover, the quantity of this sludge will be increasingly with the development of urbanization. According to the strategy of integrated management of solid waste in Vietnam up to 2025 and the vision to 2050 assigned by the Prime Minister until 2025 Vietnam must ensure that $100 \%$ of solid wastes are collected and treated, of which $90 \%$ are recycled, reused, recovered energy or produced organic fertilizer and $100 \%$ of faecal sludge in urbans and $50 \%$ in suburban is collected and treated [3]. However, in the most of urban, the majority of faecal sludge is not managed and treated properly. It is dumped directly into the environment in various forms. The private collectors often pour sludge into sewage system, fishponds and lakes illegally.The public collectors usually buried faecal sludge in the landfills. As the result, faecal

Manuscript received September 12, 2017; revised December 24, 2017.

Hoàng Lê Phương is with Thai Nguyen University of Technology, Thai Nguyen Province, Vietnam (e-mail: phuongqtn@tnut.edu.vn). sludge remains unregulated environmental pollutant in Vietnam [1].

In faecal sludge, organic matter, $\mathrm{NH}_{4}-\mathrm{N}$, total phosphorus (TP), helminth eggs are usually quite high and fluctuate depending on storage time, toilet usage and the method to empty septic tanks. In faecal sludge total volatile solid ranges from $50-73 \%$, COD from $1200-49000 \mathrm{mg} / \mathrm{l}$, BOD from $840-7600 \mathrm{mg} / \mathrm{l}, \mathrm{NH}_{4}-\mathrm{N}$ from $150-3300 \mathrm{mg} / \mathrm{l}$, worm eggs range from $4000-60000$ eggs/l [4], [5]. Faecal sludge in Hanoi city in Vietnam has COD from $15600-79500 \mathrm{mg} / \mathrm{l}$, volatile solid from 9.76-30 g/l, total nito (TN) from $80-1689$ $\mathrm{mg} / \mathrm{l}$ and TP from $82-678 \mathrm{mg} / \mathrm{l}[6]$. Thus, with the high of organic matter, faecal sludge can use as substrate for the anaerobic digestion to recover biogas. The sediment of the digestion can be used as fertilizer that is suitable for Vietnam an agriculture country, and in the context of fossil energy resourses are gradually depleted.

Carbon $(\mathrm{C})$ and nitrogen $(\mathrm{N})$ are the most demanding nutrients for microbial growth; the optimum $\mathrm{C} / \mathrm{N}$ ratio for anaerobic digestion is from 20/1 to 30/1 [7], [8]. In faecal sludge, nitrogen is usually high so it is necessary to mix faecal sludge with other waste that has high carbon ingredient to ensure proper nutrient condition. The mixing of different types of wastes in anaerobic digestion help balancing nutrient $(\mathrm{C} / \mathrm{N})$, diluting toxic factors, improving microbial density and increasing yield of biogas [9]. Zhang et al., (2017) [10] also agree that the mixing with the high $\mathrm{C} / \mathrm{N}$ waste will achieve high efficiency in anaerobic digestion of human feces. Valencia et al., (2009) concluded that when mixing faecal sludge and municipal solid waste in the landfill increased the large of biogas and helped the process more stabilize [11]. A study in Indian, when mixing food waste and faecal sludge in 1:2 ratio about volatile solid helped balancing nutrient and the yield of biogas higher [12]. In Vietnam, Nguyen Viet Anh (2014) has argued that mixing organic solid wastes such as kitchen waste that have the high carbon element with faecal sludge balanced $\mathrm{C} / \mathrm{N}$ ratio that is facility for digestion process [6].

Municipal solid waste has high carbon ingredient, in Vietnam the amount of this waste is rising rapidly about 32,000 tons/day by 2014 and continues to increase by about $12 \%$ annually. The generation sources of municipal solid waste are mainly from households, markets, commercial centers with organic content ranging from 54\% to 77\% [13]. Nowadays, they amainly handled by landfill. Therefore, the mixing of faecal sludge with these will help to guarantee bout nutrient demand $(\mathrm{C} / \mathrm{N}$ ratio) and increase the rate of recovery of municipal solid waste.

In continuous digestion, organic loading rate is an important factor that influences to efficiency of the process. Organic loading rate (OLR) is the amount of organic matter 
(express as volatile solid or COD of feeding substrate) that be treated per certain volume in a certain period. The value of OLR is mostly couple with the hydraulic retention time (HRT). If the concentrate of organic matter in feeding material is stable, the shorter the HRT the higher value of OLR be achieved. Otherwise, with the same HRT, the OLR wil vary with the different feeding substrates. The rapid increase in the OLR would be the hydrolysis and acidogenesis would occure rapidly. Meanwhile, the methanogenic bacteria is slower, they could not be able to consume the fatty acids at the same rate. This would lead to accumulation of fatty acids that cause of $\mathrm{pH}$ drecrease and inhibit the activity of methanogenic bacteria [14]. A study with mixed fruit-vegetable waste and manure in mesophilic anaerobic digestion, the suitable OLR is $1.3 \mathrm{kgVS} / \mathrm{m}^{3}$.day [1]. In Indian in dry anaerobic digestion of organic solid with HRT of 30 days in mesophilic condition, the optimum OLR is $3.1 \mathrm{kgVS} / \mathrm{m}^{3}$.day. In Vietnam, according Nguyen Viet Anh (2014) the suitable OLR for thermophilic digestion of faecal sludge and kitchen waste is $1.5 \mathrm{kgCOD} / \mathrm{m}^{3}$.day [6]. However, Vietnam is a tropical country that is very fit for mesophilic anaerobic digestion (the temperature of the digestion from 30
${ }^{0} \mathrm{C}$ to $42{ }^{0} \mathrm{C}$ ). Nowadays, it has not any clear results about the optimum OLR of mixing faecal sludge and organic waste in mesophilic digestion. Therefore, the purpose of the present study is to evaluate the effect of different loading rates on the anaerobic digestion of mixing faecal sludge and organic waste with climatic condition in Vietnam.

\section{METERIAL AND METHOD}

\section{A. Feedstock}

Faecal sludge (FS): Faecal sludge sucked in public and household toilets and was collected in the sludge tank at the Tan Cuong solid waste treatment area in Thai Nguyen Vietnam. The tank stirred and then took the suitable volume for the experimental reactor.

Organic waste $(O W)$ : Organic waste was collected at the markets. It included the fruits and vegetable removed. The organic waste collected at 6-8 am and it transferred to the experimental reactor immediately. The organic waste was chopped into size from 1 to $3 \mathrm{~cm}$ and mixed well. The characteristics of FS and OW show in Table I.

TABLE I: THE CHARACTERISTIC OF FEEDSTOCK

\begin{tabular}{llllr}
\hline Feedstock & TS $(\%)$ & VS $(\% \mathrm{TS})$ & TKN $(\mathrm{mg} / \mathrm{gTS})$ & TOC (mg/gTS) \\
\hline FS & $4.21-4.58$ & $67.75-72.24$ & $27.58-30.07$ & $305.51-345.28$ \\
\hline OW & $45.37-47.64$ & $78.39-80.42$ & $8.67-9.32$ & $378.67-427.16$ \\
\hline
\end{tabular}

\section{B. Experimal Reactor}

The experiments were carried on composite biogas tank with radium is $1.9 \mathrm{~m}$ according to Fig 1. The composite biogas tank is buried deep underground $1.9 \mathrm{~m}$ to decreasing the influent of the weather. The reactor consists of two halves, the under half contains anaerobic digestion material and the upper half contains biogas. The input material must be higher than zero level to ensure that biogas cannot escape to the air. The biogas produced will be stored at the upper half and will increase the pressure, when the high pressure will push the decomposition liquid into the two inlet and outlet doors which have role as regulating the pressure. When the biogas is dircharged, the pressure will decrease and the decomposition liquid in the two inlet and outlet doors will go down the under half of the reactor. This continuous oscillation plays the role as the natural stirring and breaking of the scum in the decomposition reactor. The pressure generated by biogas in the upper half monitored regularly by the pressure meter to avoid excessive pressure causing fail reactor. The biogas discharged continuously through gas meter and light for the biogas lamp.

The experiment was conducted in 3 trials, each trial was lasting 60 days. The material faecal sludge and organic waste were analyzed for parameters: moisture, $\mathrm{pH}$, TS, VS, TOC, $\mathrm{TN}$. The mixed material was initially loaded to $1.9 \mathrm{~m}^{3}$ into the reactor and kept for anaerobic digestion for the first 30 days. Then it continuously fed at $1.0 \pm 0.1 \mathrm{kgVS} / \mathrm{m}^{3}$.day in Trail 1 (T1), $1.5 \pm 0.1 \mathrm{kgVS} / \mathrm{m}^{3}$.day in Trail 2 (T2) and $2.0 \pm 0.1$ $\mathrm{kgVS} / \mathrm{m}^{3}$.day in Trail3 (T3) from the day 31 to 60 . Daily monitoring parameters were temperature in the reactor, gas output. The leachate sample was taken each 3 days to monitor $\mathrm{pH}$ and alkalinity.

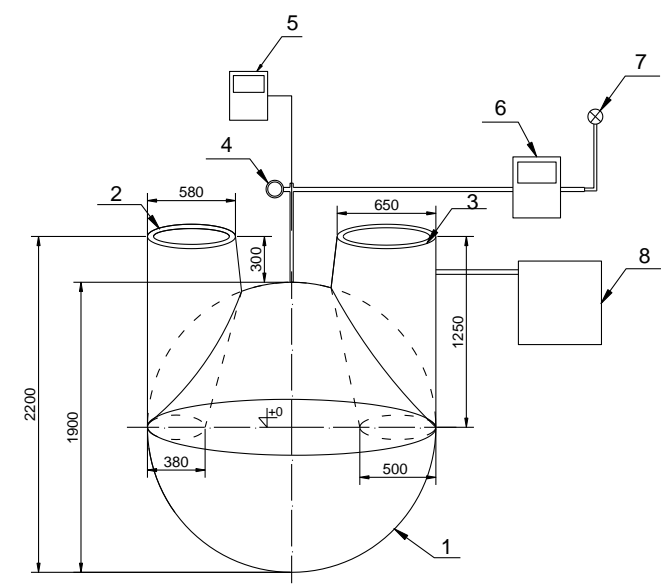

Note:

1.Composite biogas tank 5. Thermometer

2. Input sample 6. Gas meter

3. Output door 7. Biogas lamp

4. Pressure meter

8. Outlet leachate tank

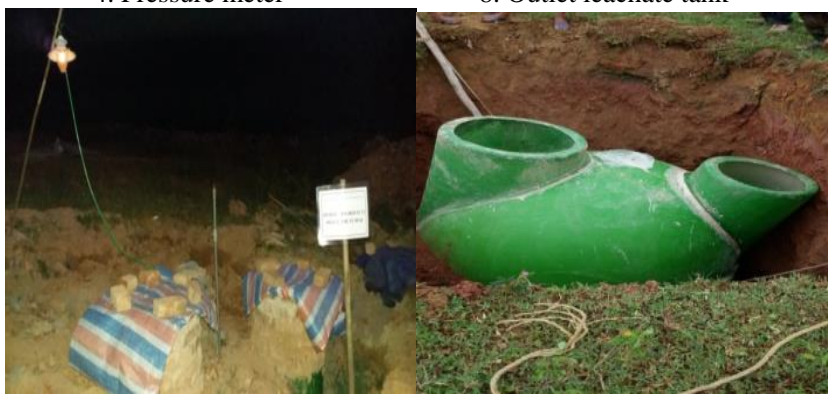

Fig. 1-3. Schematic diagram of the experimental reactor. 


\section{Analytical Methods}

The $\mathrm{pH}$ values measured with $\mathrm{pH}$ meter (Model: HI 98107 - Hanna),TS, VS, TKN and alkalinity were determined according to Standard Methods (APHA, 1995). Total organic carbon (TOC) was determined using a Shimadzu analyzer. The temperature in the reactor and the cumulative biogas measured by thermometer and gas meter respectively that attached with the reactor as fig 1 . The percentage of $\mathrm{CH}_{4}$ and $\mathrm{CO}_{2}$ in the biogas analyzed using an infrared gas analyzer (Model AOB5964T).

\section{RESUlT AND DISCUSSION}

\section{A. The Change of Some Factors During Anaerobic Digestion}

\section{1) The change of temperature in the reactor}

Temperature is an important factor influencing the process efficiency. The temperature in all three trials is in the range of $30^{\circ} \mathrm{C}-40^{\circ} \mathrm{C}$; this range is of mesophilic temperature [15], [16].

The temperature in the first 30 days: although three trials conducted in winter conditions but the temperature of the feedstock of three trials was different leading to different decomposition rate resulting in increase of temperature in the reactor was different. The first day of the first experiment (T1) had the highest temperature of $25.3{ }^{\circ} \mathrm{C}$ and the temperature of this trial also increased the fastest, after 7 days the temperature increased to $30.7{ }^{\circ} \mathrm{C}$ and after 15 days the temperature rose to $37{ }^{\circ} \mathrm{C}$ the highest in 3 trails. The initial temperature of the second experiment (T2) was $18.7{ }^{\circ} \mathrm{C}$ lower than the first experiment so the temperature increased slower. After 13 days, the temperature only reached $30{ }^{\circ} \mathrm{C}$ and after 18 days, the temperature reached $36{ }^{0} \mathrm{C}$. The initial temperature of the third experiment (T3) was only $13.7{ }^{\circ} \mathrm{C}$ so the temperature rised the slowest. After 17 days, the temperature only reached $30.5{ }^{\circ} \mathrm{C}$ and after 20 days, the temperature reached $35{ }^{\circ} \mathrm{C}$ the lowest in 3 trails. During the first 30 days of the three experiments, the temperature of the reactor tended to increase to the highest temperature range of $35-37{ }^{\circ} \mathrm{C}$, remained stable for 7 - 9 days and then dropped to 32-33 ${ }^{0} \mathrm{C}$ on the 30 day.

Anaerobic digestion is a complex process involving four stages of hydrolysis, acidogenisis, acetogenisis and methanogenisis [16]. It includes exothermic and endothermic reactions, the hydrolysis and acetogenisis require energy while acidogenisis and methanogenisis provide energy [17]. The anaerobic digestion of most energy crops is exothermicand it is self-heating process [18]. If the material has temperature of $20{ }^{\circ} \mathrm{C}$, it does not need to provide energy for the digestion in the mesophilic operation. In this study, the temperature increased due to the heat of acidogenisis and methanogenisis was sufficient to bring the reaction temperature increase to the appropriate temperature of the mesophilic condition $35-37{ }^{\circ} \mathrm{C}$. In addition, the reactor buried deep underground soit decreased the loss of heat through the device and the influence of the ambient temperature. This showed that in the winter condition of northern Vietnam, the temperature change in the anaerobic reactor is still quite good that suitable with the mesophilic condition.

In the continuous feeding stage from day 31 to 60 , the change of temperature in reactor was due to the decomposition of the organic matter and temperature of the additional feeding. With the different loading, the temperature variation in the reactor was different in three trails. In T1 with the loading feed $1.0 \pm 0.1 \mathrm{kgVS} / \mathrm{m}^{3}$.day, the temperature of the reactor was almost unaffected by the temperature of feed. It increased immediately on the day 32 and reached of $36.2{ }^{0} \mathrm{C}$ on the day 44 . After that, the temperature fluctuated from $33.5{ }^{\circ} \mathrm{C}$ to $36{ }^{\circ} \mathrm{C}$ to day 60 . In T2, the loading was $1.5 \pm 0.1 \mathrm{kgVS} / \mathrm{m}^{3}$, the temperature dropped slightly to $30{ }^{\circ} \mathrm{C}$ on the day 34 and then increased to $36{ }^{\circ} \mathrm{C}$ on the day 45 . After that, the temperature ranged from $34{ }^{\circ} \mathrm{C}$ to $36{ }^{\circ} \mathrm{C}$ to day 60. In T3, the loading was $2.0 \pm 0.1 \mathrm{kgVS} / \mathrm{m}^{3}$, the temperature of reactorhad been affected more. The temperature dropped to $28.3{ }^{\circ} \mathrm{C}$ on the day 37 and then the temperature slowly reached to $34.5{ }^{\circ} \mathrm{C}$ on the day 47 , then it ranged from $33{ }^{0} \mathrm{C}$ to $34.5{ }^{\circ} \mathrm{C}$ to day 60 . Thus, in large amounts of feedstock, the energy generated by the decomposition process was not large enough to overcome the influence of the feed temperature to increase temperature of process to $35{ }^{0} \mathrm{C}-37{ }^{0} \mathrm{C}$, the optimum temperature of the mesophilic condition.

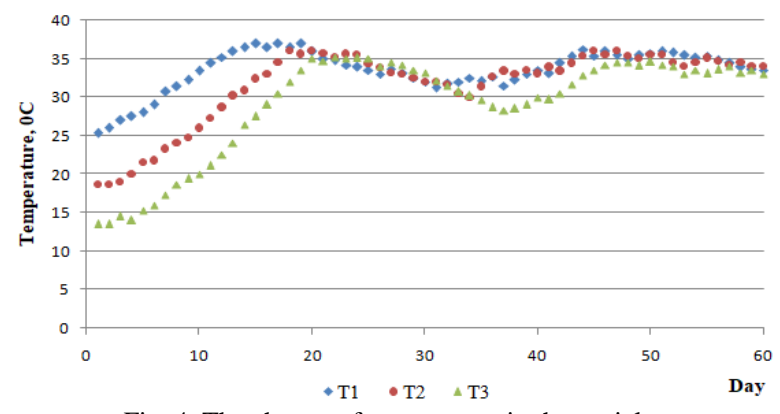

Fig. 4. The change of temperature in three trials.

\section{2) Leachate characteristics}

In the anaerobic digestion, $\mathrm{pH}$ is the most sensitive parameters. Most anaerobic bacteria operate at the suitable $\mathrm{pH}$ of 6.5 to 7.5 , optimally from 6.8 to 7.2. The methane production can reduce if the $\mathrm{pH}$ is less than 6.3 or greater than 7.8 [19], [20]. The acidogenisis generates volatile fatty acids (VFAs) that usually cause decreasing of $\mathrm{pH}$. In the case of fatty acid accumulation, the $\mathrm{pH}$ can reduce to a low level inhibiting methanogenic bacteria [12]. In the early days of the process, $\mathrm{pH}$ in the leachate dropped to 6.6 on day 9 for the $\mathrm{T} 1$ and $\mathrm{T} 2$, and 6.5 on the 12 day for the $\mathrm{T} 3$ due to volatile fatty acids (VFAs) formation. However, after that $\mathrm{pH}$ rised and ranged from 6.8 to 7.4 substantially to the 30 day because the anaerobic digestion reached the methanogenesis stage, the concentration of ammonia increased and the $\mathrm{pH}$ value also rised. This showed that the digestion of mixing faecal sludge and solid waste had good buffer capacity. Buffering capacity is the alkalinity of the decomposition mixture consisting of bicarbonate, carbonate, ammonia, and hydroxide components that help to stabilize the $\mathrm{pH}$ of the process [14], [21]. The bicarbonate alkalinity in the range of 2.0 to 5.0 $\mathrm{gCaCO}_{3} / 1$ could provide a safe buffering capacity for anaerobic digestion of waste [22]. In this study, alkalinity in 
leachate in all 3 experiments tended to increase slightly and fluctuated from $2000-2800 \mathrm{mgCaCO}_{3} / 1$ in the first 30 days.

During the loading stage from day 31 to 60 , at different loading rates there were some differences in the $\mathrm{pH}$ of leachate: in $\mathrm{T} 1$ with the loading dose of $1.0 \pm 0.1 \mathrm{kgVS} \mathrm{m}{ }^{3}$.day, $\mathrm{pH}$ was quite stable oscillation from 7.0 to 7.4 . When increasing loading rate to $1.5 \pm 0.1 \mathrm{kgVS} / \mathrm{m}^{3}$.day (in T2) the $\mathrm{pH}$ droped to 6.5 in the first days then increased and fluctuated steadily from 6.7 to 7.3 . This indicated that the buffering capacity ofthe process was good. As the loading rate continued increasing to $2.0 \pm 0.1 \mathrm{kgVS} / \mathrm{m}^{3}$ in $\mathrm{T} 3$, the $\mathrm{pH}$ dropped to 6.3 after 6 days due to accumulation of VFAs higher than in the T1 and T2. According Manser, 2015 [23] with excessive organic loading rate caused the accumulation of VFAs and decreased $\mathrm{pH}$. After that in $\mathrm{T} 3 \mathrm{pH}$ in leachate rised and range from 6.5 to 7.0 that was still appropriate for methane bacteria. However, the alkalinity at the loading rate $2 \pm 0.1 \mathrm{kgVS} / \mathrm{m}^{3}$ tended to decrease from $2572 \mathrm{mgCaCO}_{3} / \mathrm{l}$ on day 30 to $2134 \mathrm{mg} \mathrm{CaCO}_{3} / \mathrm{l}$ on day 60 . This suggested that buffering capacity at this loading decreasing, if continue to increase the loading rate, the $\mathrm{pH}$ of the process can be drastically reduced and hard to increase again. Azadeh and Jalal 2011 [24] reported that when increasing organic loading rate of the anaerobic digestion of vegetable waste to 2.75 $\mathrm{kgVS} / \mathrm{m}^{3}$.day, $\mathrm{pH}$ decreased from 7.3 to 6.8 and the alkalinity also droped.

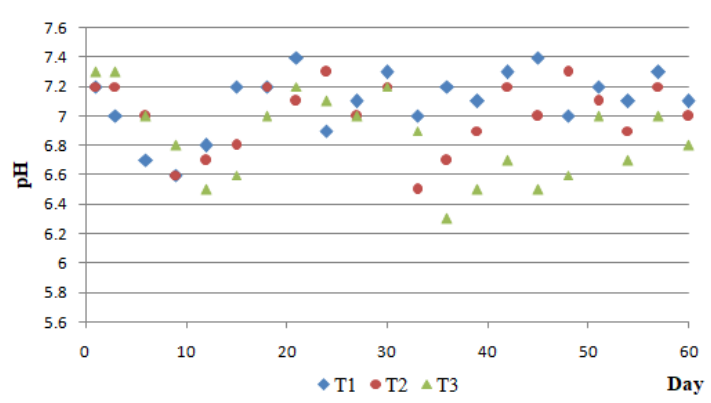

Fig. 5. The change of $\mathrm{pH}$ in leachate of three trails.

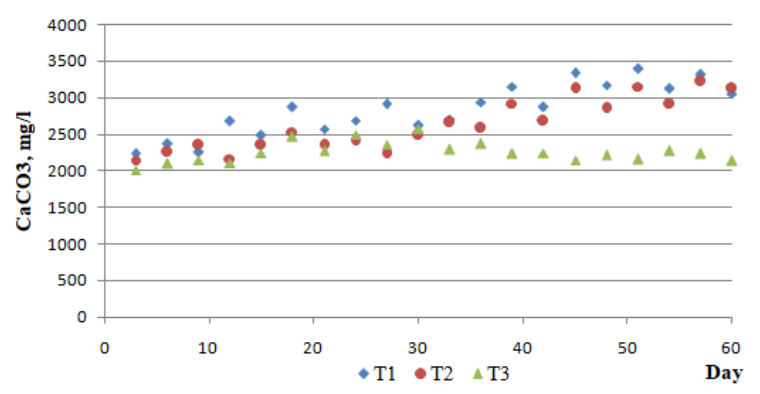

Fig. 6. The change of alkalinity in leachate of three trails.

\section{B. Biogas Production and Component}

\section{1) Biogas production}

In the first 30 days: The temperature of the feedstock in T1 was the highest, the biogas generated also the largest and fastest. In T3, the temperature of the feedstock was the lowest and the biogas generation was the smallest and slowest. However, the different between three trails was not much. The maximum daily biogas production obtained for $\mathrm{T} 1$ was from 3213 to $3670 \mathrm{Nl} /$ day from day 14 to 21 and that for T2 was from 3005 to $3529 \mathrm{Nl} /$ day from day 16 to 23 and for T3 was from 2768 to $3362 \mathrm{Nl} /$ day from day 17 to 25 . The cumulative biogas after the first 30 days for T1 was $60207 \mathrm{Nl}$ equivalent to $485.23 \mathrm{Nl} / \mathrm{kgVS}$ of feed, for T2 was $57578 \mathrm{Nl}$ equivalent to $455.52 \mathrm{Nl} / \mathrm{kgVS}$ of feed and for M3 was 52817 $\mathrm{Nl}$ equivalent to $426.94 \mathrm{Nl} / \mathrm{kgVS}$ of feed. In all three trails of the first 30 days, the biogas production increased gradually and reached the highest level in the range of 14-25 days then decreased gradually. This showed that in the period from the day 14 to 25 , the methanogenisis stage occurred strongly with the suitable conditions for anaerobic digestion. The temperature was from 35 to $37{ }^{\circ} \mathrm{C}, \mathrm{pH}$ from $7-7.3$, alkalinity from 2400 to $2900 \mathrm{mgCaCO}_{3} / \mathrm{l}$.

After the first 30 days the temperature in the reactor of all three trails was over $30{ }^{\circ} \mathrm{C}$, conditions such as $\mathrm{pH}$ and alkalinity were quite suitable for anaerobic digestion. In the continuous feeding stage from day 31 to 60 with the different about organic loading rate in each experiment, there was the distinct difference between three trails. Organic loading rate is an important parameter of the process. If it is too low, the amount of gas produced is low. In contrast and if it is too high leads to the fatty acid accumulation that causes $\mathrm{pH}$ droping and failure process [14]. Therefore, with the different loading rate, the amount of biogas production is different. In this study, in $\mathrm{T} 1$ with the loading rate $1.0 \pm 0.1 \mathrm{kgVS} / \mathrm{m}^{3}$.day the average amount of biogas produced $284 \mathrm{Nl} / \mathrm{kgVS}$ of the feed. In $\mathrm{T} 2$ with $1.5 \pm 0.1 \mathrm{kgVS} / \mathrm{m}^{3}$.day, the average amount of biogas was $490.32 \mathrm{Nl} / \mathrm{kgVS}$ of the feed and in T3 with $2.0 \pm 0.1 \mathrm{kgVS} / \mathrm{m}^{3}$.day the biogas was $236.11 \mathrm{Nl} / \mathrm{kgVS}$ of the feed. It can see that, when the daily loading rate increased from $1.0 \pm 0.1 \mathrm{kgVS} / \mathrm{m}^{3}$.day (in T1) to $1.5 \pm 0.1 \mathrm{kgVS} / \mathrm{m}^{3}$.day (in T2) the biogas production also rised significantly. However, when increasing the loading rate $2.0 \pm 0.1$ $\mathrm{kgVS} / \mathrm{m}^{3}$.day (in T3) the biogas production reduced compare to T2. As such, the daily loading rate affected greatly the biogas production. Alvarez and Liden (2007) [25] argued that in co-digestion manure and fruit-vegetable waste, the optimum organic loading rate was $1.3 \mathrm{kgVS} / \mathrm{m}^{3}$.day. Azadeh and Jalal (2011) [24] concluded that the suitable organic loading rate in digestion vegetable waste was 1.4 $\mathrm{kgVS} / \mathrm{m}^{3}$.day with specific yield of biogas was 0.25 $\mathrm{m}^{3} \mathrm{CH}_{4} / \mathrm{kgVS}$. When rising to $2.0 \pm 0.1 \mathrm{kgVS} / \mathrm{m}^{3}$, the productivity decreased. In this study, the organic loading rate of $1.5 \pm 0.1 \mathrm{kgVS} / \mathrm{m}^{3}$.day was the optimum. Because the anaerobic digestion process in the reactor was good and the biogas product was the largest. With the loading rateof $1.0 \pm 0.1 \mathrm{kgVS} / \mathrm{m}^{3}$.day, the process was good but the biogas generation was lower due to less substrate. With the high loading rate of $2.0 \pm 0.1 \mathrm{kgVS} / \mathrm{m}^{3}$.day, the process was slowler and the amount of biogas was smaller.

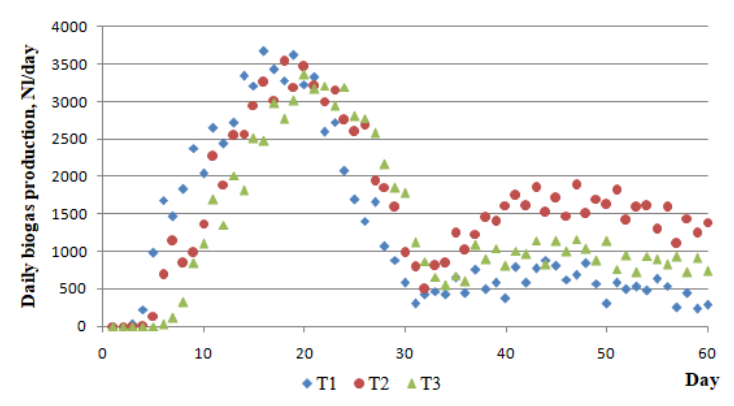

Fig. 7. Daily biogas production in three trails. 


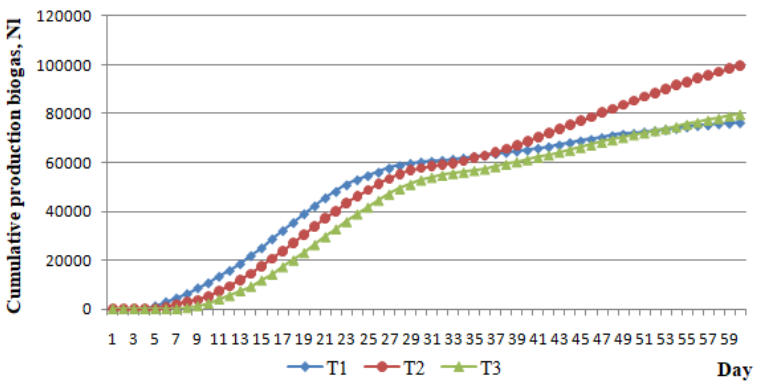

Fig. 8. Cumulative biogas production in three trails.

\section{2) Biogas component}

The biogas generated from the reactor in all three trails was used to illuminate the biogas lamp directly and periodically determined the $\mathrm{CH}_{4}$ and $\mathrm{CO}_{2}$, the results shown in the Table II.

TABLE II: BIOGAS COMPONENT IN 3 TRAILS

\begin{tabular}{lcccccc}
\hline & \multicolumn{2}{c}{$\mathrm{T} 1$} & \multicolumn{2}{c}{$\mathrm{T} 2$} & \multicolumn{2}{c}{$\mathrm{T} 3$} \\
\cline { 2 - 7 } Day & $\mathrm{CH}_{4}$ & $\mathrm{CO}_{2}$ & $\mathrm{CH}_{4}$ & $\mathrm{CO}_{2}$ & $\mathrm{CH}_{4}$ & $\mathrm{CO}_{2}$ \\
\hline Day 5 & 31.6 & 62.5 & 20.4 & 75.2 & - & - \\
\hline Day 15 & 70.3 & 25.4 & 69.2 & 25.3 & 64.4 & 28.6 \\
\hline Day 25 & 68.5 & 28.7 & 66.8 & 28.2 & 69.2 & 26.4 \\
\hline Day 35 & 65.1 & 28.2 & 60.5 & 34.8 & 42.3 & 53.5 \\
\hline Day 45 & 69.2 & 27.6 & 67.4 & 27.7 & 46.7 & 47.3 \\
\hline Day 55 & 68.6 & 28.1 & 65.1 & 29.6 & 48.3 & 47.2 \\
\hline
\end{tabular}

In the first 30 days, the biogas samples analyzed for $\mathrm{CH}_{4}$ and $\mathrm{CO}_{2}$ on the day $5,15,25$. On the day 5 , the $\mathrm{CH}_{4}$ content was lower whereas the $\mathrm{CO}_{2}$ content was higher, especially in the third experiment with no gas because these days hydrolysis and acidification were dominant. Although on the day 5 , the composition of $\mathrm{CH}_{4}$ was low but it still reached $31.6 \%$ in the T1 and $20.4 \%$ in the T2. This showed that the methanogenesis stage occurred quite fast. As the faecal sludge was in the septic tank, an anaerobic environment and there was a large amount of methanogenic bacteria. This result was similar to some other reported results, according to Azadeh and Jalal (2011) [24], when digestion vegetables wastes added anaerobically sludge $\mathrm{CH} 4$ content reached 40-50 \% on day 5. According to Jun et al, (2016) [19], when mixing cassava pulp with sewage sludge in anaerobic digestion, the $\mathrm{CH}_{4}$ content was higher than $40 \%$ in the early days. It can compare anaerobically sludge and sewage sludge to faecal sludge because they were also sludge from anaerobic processes; vegetables waste and cassava pulp tothe organic waste from market because of the high levels of carbohydrates. On the day 15 , when the biogas product was quite large in all three trails, the $\mathrm{CH}_{4}$ content increased significantly by $70.3 \%$ for the T1, $69.2 \%$ for the T2 and $64.4 \%$ for the T3. On the day 25 of the process, when the amount of biogas generation decreased, the $\mathrm{CH}_{4}$ content was lower than on the day 15 but still accounts for a relatively high $68.5 \%$ for theT1, $66.8 \%$ for theT 2 and $69.2 \%$ for the
T3. Thus, after 30 days $\mathrm{CH}_{4}$ concentration in biogas in all three trails was almost like together, the anaerobic digestion was good in the outdoor model at the $\mathrm{PB}: \mathrm{RC}=3: 1$ ratio about the weight, with $\mathrm{CH}_{4}$ more than $60 \%$.

In the continuous loading stage from the day 31 to 60 : In $\mathrm{T} 1$ with the organic loading rate of $1 \pm 0.1 \mathrm{kgVS} / \mathrm{m}^{3}$.day, $\mathrm{CH}_{4}$ content was quite high and stable with $65.1 \%$ on the day 35 , $69.2 \%$ on the day 45 and $68.6 \%$ on the day 55 . When increasing loading rate to $1.5 \pm 0.1 \mathrm{kgVS} / \mathrm{m}^{3}$.day in $\mathrm{T} 2$ the $\mathrm{CH}_{4}$ concentration on day 35 was $60.5 \%$ lower than in $\mathrm{T} 1$. However, in the following days, the $\mathrm{CH}_{4}$ content in $\mathrm{T} 2$ increased by $67.4 \%$ on day 45 and $65.1 \%$ on day 55 . As continues to increase at loading rate of $2 \pm 0.1 \mathrm{kgVS} / \mathrm{m}^{3}$ in T3, the $\mathrm{CH}_{4}$ content on the day 35 was $42.3 \%$, significantly lower than in $\mathrm{T} 2$ and $\mathrm{T} 3$. In the following days, the percentage of $\mathrm{CH}_{4}$ in this trail increased but only at $46.7 \%$ on the day 45 and $48.3 \%$ on the day 55 day. Thus, at the overloading the methane content decreased while the $\mathrm{CO}_{2}$ content increased. Some researches reported that at so high organic loading the methane yield could rapidly reduce [10], [24].

The measurement of the quantity and composition of the biogas produced is of fundamental important to evaluate the performance of the process. It can see that with different loading rates, efficiency of the process were different. With loading rate $1 \mathrm{kgVS} / \mathrm{m}^{3}$.day the $\mathrm{CH}_{4}$ content observed was the highest, however the yieldof biogas only was 284 $\mathrm{N} 1 / \mathrm{kgVS}$ that was lower than in T2. When increasing the loading rate at $1.5 \pm 0.1 \mathrm{kgVS} / \mathrm{m}^{3}$.day, the biogas production rised to $490.32 \mathrm{Nl} / \mathrm{kgVS}$ and $\mathrm{CH}_{4}$ content was pretty high.When continuous increasing the loading rate at $2 \pm 0.1$ $\mathrm{kgVS} / \mathrm{m}^{3}$.day, the yield of biogas droped to $236.11 \mathrm{Nl} / \mathrm{kgVS}$ and $\mathrm{CH}_{4}$ content was the lowest. Therefore, it can see that at loading rate $1.5 \pm 0.1 \mathrm{kgVS} / \mathrm{m}^{3}$.day was suitable in this study.

\section{CONCLUSION}

From the results obtained about some charactiristics of process such as temperature in reactor, $\mathrm{pH}$, alkalinity and biogas production, it can besee that the anaerobic digester of mixed faecal sludge and organic waste should preferably run at loading rate of $1.5 \pm 0.1 \mathrm{kgVS} / \mathrm{m}^{3}$. day due to maximum biogas product was obtained in $490.32 \mathrm{Nl} / \mathrm{kgVS}$ and high $\mathrm{CH}_{4}$ content with more than $60 \%$. It was observed that at higher loading rate $2 \pm 0.1 \mathrm{kgVS} / \mathrm{m}^{3}$.day, the process affected negatively with decreasing the amount of biogas and $\mathrm{CH}_{4}$ content. The efficiency of biogas recovery from the anaerobic digestion of mixed faecal sludge and organic waste in Vietname climatic condition is quite high if it is operated at the suitable organic loading rate and condition.

\section{REFERENCES}

[1] World Bank, Assessment of the Urban Wastewater Management in Vietnam, 2012

[2] Ho Chi Minh City Urban Drainage Co., Ltd, "Sewer and feacal sludge management in Ho Chi Minh City," in Proc. the 3RD International Feacal Sludge Management Conference, Focus on Vietnam, pp. 28-29, 2015.

[3] The Prime Minister's Office, "The strategy of intergated management of solid waste in Vietnam up to 2025 and the vision to 2050," 2009.

[4] U. Heinss, S. A. Larmie, and M. Strauss, "Solids separation and pond systems for the treatment of sludges in the tropics. Lessons learn and 
recommendations for preliminary design," SANDEC Report, Swiss Federal Institute for Environmental Science ad Technology (EAWAG) and Water Research Institute (WRI), Accra/Ghana, 1998.

[5] D. Kone and M. Strauss, "Low-cost options for treating sludges (FS) in developing countries - Challenges and performance," presented at the 9th International IWA Specialist Group Conference on Wetlands Systems for Water Pollution Control and the 6th International IWA Specialist Group Conference on Waste Stabilisation Ponds, Avignon, France, 2004.

[6] N. V. Anh, "Study on solution for synthetic collecting and treating waste according to semi-centralized model for urbans in Vietnam. Case study in Hanoi," Protocol Program about Science and Technology with Germany, National University of Civil Engineering, Hanoi, 2014.

[7] G. Tchobanoglous, H. Theisen, and S. Vigil, Integrated Solid Waste Management, Engineering Principles and Management Issues, McGraw-Hill international editions, ISBN: 0-07-063237-5, 1993.

[8] P. Weiland, "State of the art of solid-state digestion-recent developments," Solid-State Digestion-State of the Art and Further $R \& D$ Requirements, Gulzower Fachgespräche, vol. 24., pp. 22-38, 2006.

[9] K. Azeem, A. Muhammad, A. Muzammil, M. Tariq, and D. Lorna, "The anaerobic digestion of solid organic waste," Waste Management, vol. 31, pp. 1737-1744, 2011.

[10] J. Zhang, J. Xu, D. Wang, and N. Ren, "Anaerobic digestion of cassava pulp with sewage sludge inocula," Bioresources, vol. 11, no. 1, pp. 451-465, 2016.

[11] R. Valencia, D. Hamer, J. Komboi, H. J. Lubberding, and H. J. Gijzen, "Alternative treatment for septic tank sludge: Co-digestion with municipal solid waste in bioreactor landfill simulators," Journal of Environmental Management, vol. 90, pp. 940-945, 2009.

[12] M. Prabhu, S. Waigaonkar, R. Dube, D. Walther, and S. Mutnuri, "Anaerobic co-digestion of food waste and septage - A waste to energy project in Nashik city," Carbon - Sci. Tech, vol. 7, no. 2, pp. 87-98, 2015.

[13] The Ministry of Natural Resources and Environment, National Environment Report - Solid Waste, 2011.

[14] S. E. Nayono, "Anaerobic digestion of organic solid waste for energy production," Karlsruhe, 2009.

[15] J. M. Alvarez, "Fundamentals of the anaerobic digestion process (in:Biomethanization of the organic fraction of municipal solid wastes)," Amsterdam: IWA Publishing Company, 2002.

[16] T. A. Seadi, D. Rutz, H. Prassl, M. Köttner, T. Finsterwalder, S. Volk, and R. Janssen, Biogas Handbook, University of Southern Denmark Esbjerg, Niels Bohrs Vej 9-10, DK-6700 Esbjerg, Denmark, 2008.
[17] L. Jingquan and A. B. Kiær, "Optimization of anaerobic digestion of sewage sludge using thermophilic anaerobic pre-treatment," Ph.D.dissertation, Technical University of Denmark, 2007.

[18] H. Lindorfer, R. Braun, and R. Kirchmayr., "Self-heating of anaerobic digesters using energy crops,", vol. 53, no. 8, pp. 159-66, 2006

[19] J. Lay, Y. Li, and T. Noike, "Influences of $\mathrm{pH}$ and moisture content on the methane production in high-solids sludge digestion," Wat.Res, vol. 31 , no. 6, pp. 1518-1524, 1997

[20] S. M. Stronach, T. Rudd, and J. N. Lester, Anaerobic Digestion Processes in Wastewater Treatment, Berlin: Springer, 1986.

[21] A. G. Hashimoto, Y. R. Chen, and V. H. Varel, Anaerobic Fermentation of Beef Cattle Manure, Animal research center and Agriculture clay center - Nebraska, 1981

[22] A. S. Nizami, N. E. Korres, and J. D. Murphy, "Review of the integrated process for the production of grass biomethane," Environmental Science \& Technology, vol. 43, no. 22, pp. 8496-8508, 2009.

[23] N. D. Manser, "Effects of solids retention time and feeding frequency on performance and pathogen fate in semi-continuous mesophilic anaerobic digesters", Ph.D dissertation, University of South Florida, 2015.

[24] B. Azadeh and S. Jalal, "Effect of organic loading rates (OLR) on production of methane from anaerobic digestion of vegetables waste," presented at the World Renewable Energy Congress, Sweden, 2011.

[25] R. Alvarez and G. Liden, "Semi-continuous co-digestion of solid slaughterhouse waste, manure, and fruit and vegetable waste," Renewable Energy, vol. 33, pp. 726-734, 2007.

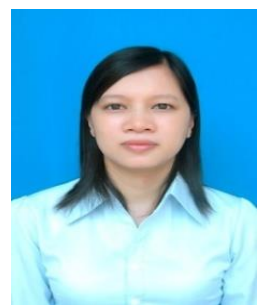

Hoang Le Phuong was born in on $23^{\text {rd }}$ November 1980. She graduated with the bachelor's degree and the master's degree in environmetal technology from School of Environmental Science and Tecchnology, Hanoi University of Science and Technology in 2003 and 2006 respectively. She has carried out this research as a part of studied for the Doctoral degree in Faculty of Environmental Engineering, National University of Civil Engineering. She is currently a head of the Department of Environmental Engineering, Faculty of Civil and Environment, Thai Nguyen University of Technology. 